\title{
REMOVAL OF NITROGEN AND ORGANIC MATTER IN AN INTERMITTENTLY AERATED HORIZONTAL SUBSURFACE FLOW CONSTRUCTED WETLAND
}

\author{
João G.T. Queluz ${ }^{1 *}$ and Marcelo L. Garcia ${ }^{2}$ \\ ${ }^{1}$ Enviromental Studies Center, Institute of Geosciences and Exact Sciences, São Paulo State University (Unesp), \\ Rio Claro-SP, Brazil. \\ ${ }^{2}$ Department of Petrology and Metallogeny, Institute of Geosciences and Exact Sciences, São Paulo State \\ University (Unesp), Rio Claro-SP, Brazil.
}

Received 7 October 2019; received in revised form 10 June 2020; accepted 08 October 2020

\begin{abstract}
The objective of this work was to evaluate the effect of intermittent aeration on the removal of ammonium $\left(\mathrm{NH}_{4}^{+}\right)$, total nitrogen $(\mathrm{TN})$ and chemical oxygen demand (COD) in a horizontal subsurface flow constructed wetland (HFCW). Two HFCWs were studied, one non-aerated and another aerated intermittently, and both cultivated with Typha latifolia. Each system received $8.6 \mathrm{~L} \mathrm{~d}^{-1}$ of synthetic wastewater, resulting in 3 days of hydraulic retention time. The two systems displayed high efficiencies in the removal of COD (>90\%); however, the intermittently aerated HFCW showed a higher rate of COD removal. Additionally, the removal of $\mathrm{TN}(48.8 \%)$ and $\mathrm{NH}_{4}{ }^{+}$ $(57.7 \%)$ in the non-aerated system was limited, while in the aerated system, the efficiencies of $\mathrm{TN}(81.2 \%)$ and $\mathrm{NH}_{4}{ }^{+}(98.6 \%)$ removal were satisfactory. Thus, the results indicate that via intermittent aeration, nitrification and denitrification occur simultaneously, improving the performance of $\mathrm{HFCW}$ in the removal of $\mathrm{TN}$ and $\mathrm{NH}_{4}{ }^{+}$.
\end{abstract}

Keywords: Artificial aeration; constructed wetlands; nutrients removal; rural sanitation; wastewater treatment

(C) 2020 Journal of Urban and Environmental Engineering (JUEE). All rights reserved.

\footnotetext{
* Correspondence to: João G.T. Queluz, Tel.: +55 1499718 0252; Fax: +551935269313.

E-mail: j.queluz@unesp.br
} 


\section{INTRODUCTION}

The treatment of domestic wastewater in isolated communities is still a global issue, primarily in developing and/or low-income countries. The distance from urban centers and the lack of public policies often make it impossible to collect and treat effluents generated in these communities, resulting in damage to the environment and human health. Thus, in recent decades, several studies have been conducted on decentralized wastewater treatment systems, including subsurface flow constructed wetlands.

Subsurface flow constructed wetlands display high efficiency in the removal of pollutants, particularly solids, organic matter, and pathogens (Abou-Elela et al., 2013; Weerakoon et al., 2013). However, owing to the limited supply of dissolved oxygen (DO) the efficiency in the removal of total nitrogen (TN) in constructed wetlands is limited (Saeed \& Sun, 2012; $\mathrm{Wu}$ et al., 2014). Nitrification is the first limiting process in the removal of $\mathrm{TN}$, since nitrifying bacteria depend upon the availability of DO (Fan et al., 2013). Thus, to allow effective nitrification, continuous artificial aeration is implemented in constructed wetlands as an alternative to supplement oxygen (Butterworth et al., 2013). Although this technique allows for nitrification, the high DO levels supplied to the system can alter the conditions of the anoxic/anaerobic medium to aerobic, inhibiting the denitrification process, which consequently limits the removal of TN (Maltais-Landry et al., 2009).

On the other hand, some recent studies show that the use of intermittent artificial aeration is preferable, as it shifts the environmental conditions between aerobic and anoxic, allowing nitrification and denitrification to occur simultaneously, increasing the $\mathrm{TN}$ removal efficiency (Fan et al., 2016; Hou et al., 2017). However, most studies evaluate the effects of intermittent aeration in vertical subsurface flow constructed wetlands (VFCW) (Fan et al., 2013; Wu et al., 2016a; Liu et al., 2019) and, therefore, there are few data in the world literature on the performance of horizontal subsurface flow constructed wetland (HFCW) with intermittent aeration. In this way, the objective of this study was to evaluate the effect of intermittent aeration on the removal of $\mathrm{NH}_{4}^{+}$, TN and chemical oxygen demand (COD) in HFCW.

\section{MATERIALS AND METHODS}

\section{Characteristics of the treatment system}

The experiment was conducted in a protected environment (greenhouse) at the Center for Environmental Studies (CEA) - UNESP, Rio Claro, SP, Brazil. Two HFCWs were evaluated at a pilot scale (CW1: not aerated; and CW2: aerated intermittently). Each HFCW was comprised of a rectangular polypropylene water tank with an approximate capacity of $61 \mathrm{~L}(31.0 \times 35.5 \times 55.5 \mathrm{~cm})$ filled with gravel \#0 (Ø $=2.4-9.5 \mathrm{~mm}$ ) with a porosity of $53 \%$. The water tanks were filled with gravel up to a height of $30 \mathrm{~cm}$ and the level of the effluent was maintained at $25 \mathrm{~cm}$, resulting in saturated volume of approximately $26 \mathrm{~L}$. The systems were cultivated with Typha latifolia. CW2 was aerated intermittently for $3 \mathrm{~h}$ day $^{-1}(1 \mathrm{~h}$ aeration/ $7 \mathrm{~h}$ without aeration) at an aeration rate of $10 \mathrm{~L} \mathrm{~min}^{-1}$. Air was applied to the system using a tube diffuser installed at the bottom and along the longitudinal section of the polypropylene tank. The schematic diagram of the constructed wetlands is shown in Fig. 1.

\section{System operation, origin of the influent and hydraulic retention time}

The systems were operated continuously for 250 days from April 4, 2018 to December 7, 2018. The synthetic effluent was prepared using feed water with the addition of $387 \mathrm{mg} \mathrm{L}^{-1}$ sucrose, $188 \mathrm{mg} \mathrm{L}^{-1}\left(\mathrm{NH}_{4}\right)_{2} \mathrm{SO}_{4}, 18 \mathrm{mg} \mathrm{L}^{-1}$ of $\mathrm{KH}_{2} \mathrm{PO}_{4}, 10 \mathrm{mg} \mathrm{L}^{-1}$ of $\mathrm{MgSO}_{4}, 10 \mathrm{mg} \mathrm{L}^{-1}$ of $\mathrm{FeSO}_{4}$, and $10 \mathrm{mg} \mathrm{L}^{-1}$ of $\mathrm{CaCl}_{2}$, as described in the works of Fan et al. (2016), Wu et al. (2015a) and $\mathrm{Wu}$ et al. (2016a). Using the peristaltic pumps, $8.6 \mathrm{~L} \mathrm{~d}^{-1}$ of synthetic effluent was applied to the HFCWs, resulting in 3 days of hydraulic retention time (HRT). Sampling points were distributed along the HFCW located at distances of $0,18.5,37$ and $55.5 \mathrm{~cm}$ from the effluent entrance zone. The HRT of each of the sampling point would be proportional to its distance relative to the beginning of the HFCWs; therefore, the HRT adopted for each sampling point was $0,1,2$, and 3 days, respectively.

\section{Sample analysis}

Five samples were collected at each sampling point to determine $\mathrm{COD}, \mathrm{NH}_{4}^{+}, \mathrm{NO}_{3}^{-}, \mathrm{NO}_{2}^{-}$, and $\mathrm{pH}$.

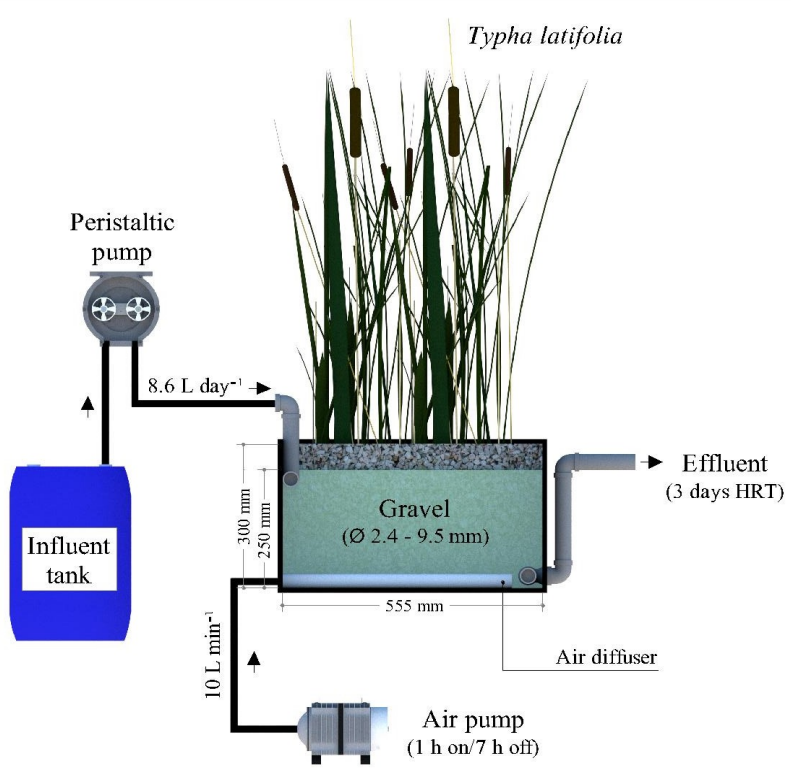

Fig. 1 Schematic diagram of the HFCWs used in the experiment. 
Table 1. Characteristics of the influent and effluent of HFCWs and their removal efficiencies (mean $\pm \operatorname{SD}, \mathrm{n}=5)$.

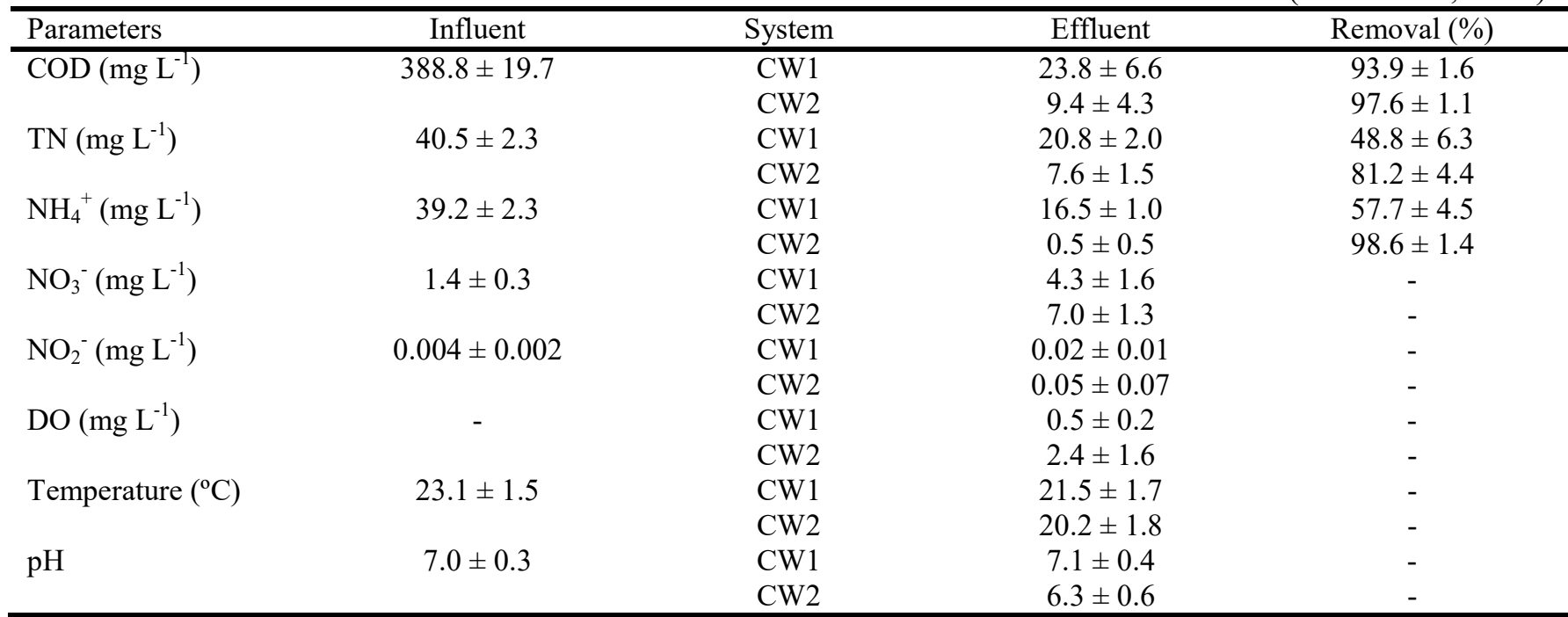

concentrations were estimated as the sum of the other forms of nitrogen. DO levels within the HFCWs were determined in situ using a portable Akso DO meter (model: DO Eco 1.00). All samples were collected, stored, and analyzed according to the methodologies described by APHA (2012).

\section{Statistical analysis}

The COD, NH4+, and TN data obtained in the HFCWs were compared via analysis of variance (ANOVA) in the statistical program Statgraphics (version 16.2. 04).

\section{RESULTS AND DISCUSSION}

Table 1 shows the characteristics of the influent and effluent of HFCWs and their removal efficiencies.

\section{DO levels}

The average DO levels of the HFCWs over an aeration cycle are shown in Fig. 2. As expected and in agreement with published data (Fan et al., 2013; Fan et al., 2016; Uggeti et al., 2016), CW1 presented an anaerobic condition with a mean DO level of $0.5 \mathrm{mg} \mathrm{L}^{-1}$ (range: $0.3-0.8)$. On the other hand, the system with intermittent aeration (CW2) had a higher average DO level: $2.4 \mathrm{mg}$ $\mathrm{L}^{-1}$ (range: 0.9-5.4). An increase in DO levels in the CW2 system occurs during aeration, and the maximum level is obtained at the end of the aeration phase. After aeration, during the $7 \mathrm{~h}$ resting period, the DO level decreases until the observed minimum value is reached. Similar DO profiles in intermittently aerated constructed wetlands were also described by Fan et al. (2013) and Wu et al. (2016b).

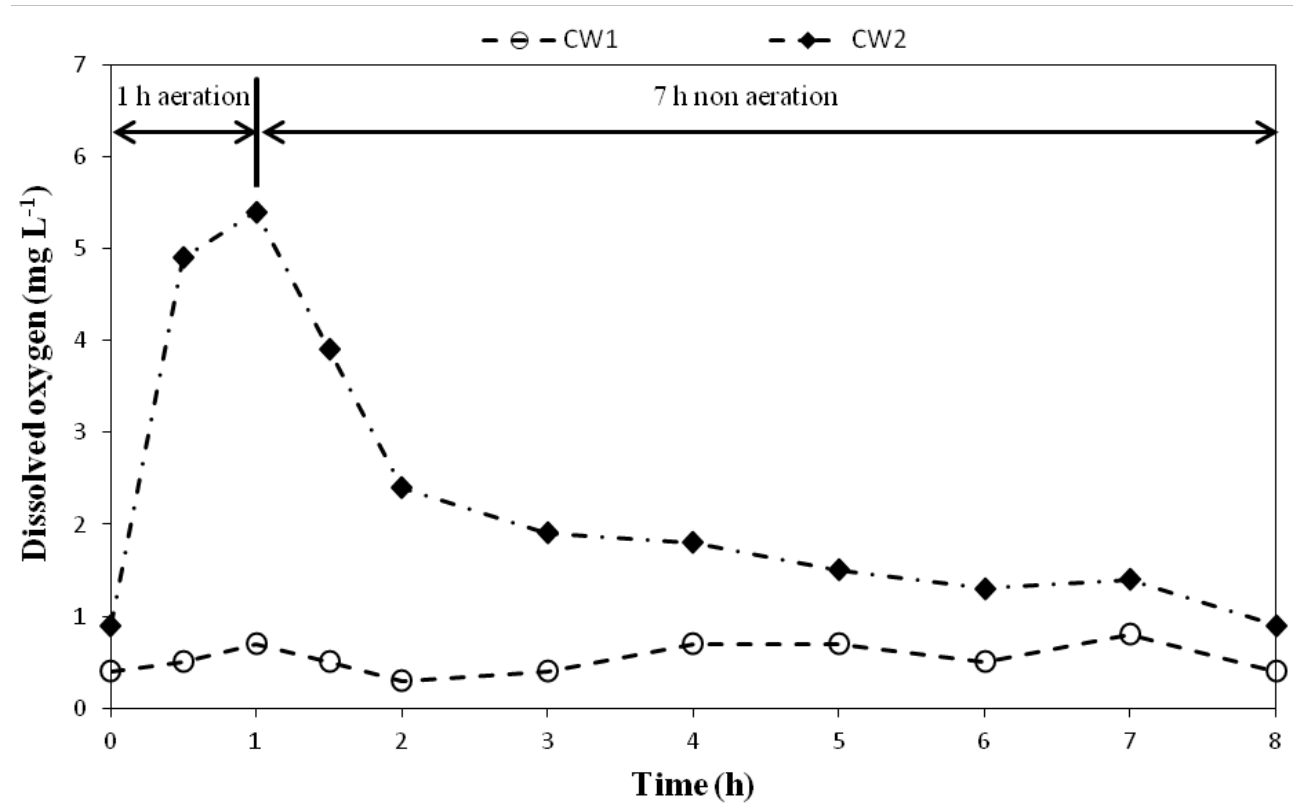

Fig. 2 Average levels of dissolved oxygen of HFCWs along an aeration cycle. 


\section{COD removal}

CW1 and CW2 displayed a COD removal of 93.9 and $97.6 \%$ respectively. COD removal difference between the systems was small; the mean COD concentration in the CW1 and CW2 effluents was $23.8 \mathrm{mg} \mathrm{L}^{-1} 9.4 \mathrm{mg} \mathrm{L}^{-}$ 1 , respectively, that is, a removal difference of only $3.7 \%$ was observed. Non-aerated HFCWs may exhibit high COD removal performance, as described by AbouElela et al. (2013), Caselles-Osorio et al. (2017) and Liu et al. (2018) who obtained efficiencies of 91.5, 80-91, and $>85 \%$, respectively. Thus, depending on the operating conditions such as HRT and effluent characteristics, the efficiency of organic matter removal in non-aerated HFCWs might be similar to that of the aerated systems. For example, Uggeti et al. (2016) reported a difference of only $1 \%$ in COD removal efficiency between a non-aerated system and another intermittently aerated system.

Although the final COD levels were similar, there was a clear difference in efficiency of removal of COD along the systems (Fig. 3). With 1 day of HRT, the average COD level in CW2 decreased to $23 \mathrm{mg} \mathrm{L}^{-1}$ and in CW1 it decreases to $119 \mathrm{mg} \mathrm{L}^{-1}$; these concentrations correspond to $94 \%$ and $69 \%$ removal efficiency, respectively. These data are similar to those reported by $\mathrm{Wu}$ et al. (2016a), in which the authors evaluated VFCWs and in only 12 hours obtained in intermittent aerated systems and in non-aerated systems COD removal efficiencies of, respectively $>88 \%\left(<50 \mathrm{mg} \mathrm{L}^{-1}\right)$ and $76-82 \%\left(75-100 \mathrm{mg} \mathrm{L}^{-1}\right)$. These results indicate that the use of intermittent aeration in constructed wetlands increases the organic matter removal rate. The increase in the COD removal rate in intermittently aerated HFCWs may be associated with the stimuli in the direct biological removal pathways (respiration/fermentation) and also to the removal of organic carbon in the nitrate reduction (part of denitrification) process (Saeed \& Sun, 2012).

\section{Nitrogen removal}

According to Saeed \& Sun (2012), the transformation and removal of nitrogen in subsurface flow constructed wetlands occurs via both classical pathways (ammonification, nitrification/denitrification, plant absorption, biomass assimilation, and volatilization of ammonia) and newly discovered pathways (partial nitrification/denitrification, ANAMMOX, and Canon process). Maltais-Landry et al. (2009) observed that TN removal is mainly associated with four processes: 1) plant absorption; 2) storage in the sediment; 3) partial nitrification/denitrification; and 4) complete nitrification/denitrification. However, complete nitrification/denitrification is considered to be the main mechanism of TN removal, accounting for $47 \%$ to $96 \%$ of nitrogen removal (Lin et al., 2002; Maltais-Landry et al., 2009; Chen et al., 2014).

With regard to the plants, a few studies have demonstrated that macrophytes are responsible for up to $34.3 \%$ of the removal of TN (Maltais-Landry et al., 2009; Wu et al., 2013; Chen et al., 2014; Liu et al., 2019). The results obtained by Maltais-Landry et al. (2009) show that, in continuously aerated subsurface flow constructed wetlands, the species Typha angustifolia was responsible for the removal of approximately $135 \mathrm{mg} \mathrm{N} \mathrm{m}^{-2} \mathrm{~d}^{-1}$, which represents $7.6 \%$ of the rate of application of nitrogen in the present study (1768 $\mathrm{mg} \mathrm{N} \mathrm{m}^{-2} \mathrm{~d}^{-1}$ ). Other authors (Wu et al., 2013) estimated rates of removal of $40 \mathrm{mg} \mathrm{N} \mathrm{m}^{-2} \mathrm{~d}^{-1}$ by Typha orientalis, representing only $2.3 \%$ of the nitrogen applied under our conditions. Therefore, in the analysis of the results obtained in the present study, we considered that complete nitrification/denitrification

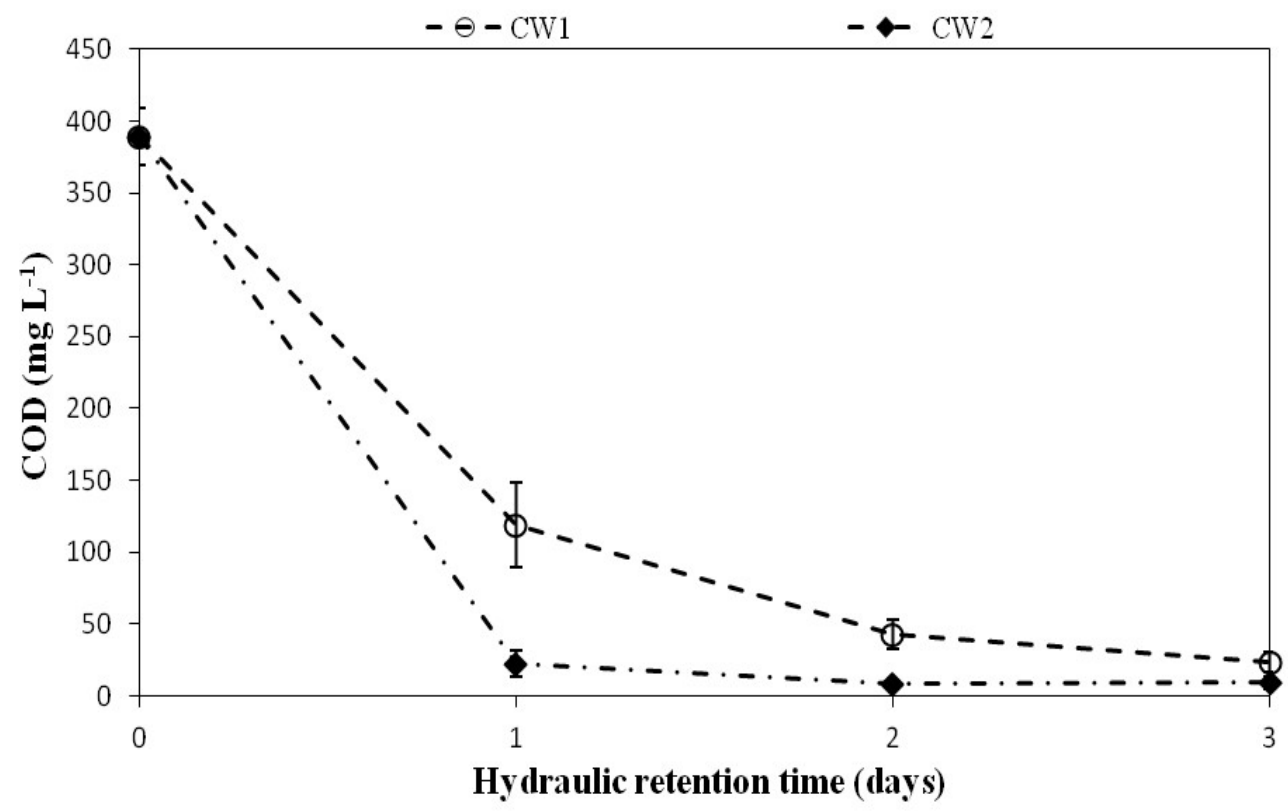

Fig. 3 Average concentrations of COD along the HFCWs. 
was the main route of $\mathrm{TN}$ removal.

The average removal of $\mathrm{NH}_{4}^{+}$and $\mathrm{TN}$ in CW1 was $57.7 \%$ and $48.8 \%$, respectively, confirming that conventional HFCWs (without aeration) have limitations in the removal of nitrogen. For example, Hua et al. (2017) reported the removal of $\mathrm{NH}_{4}^{+}$and $\mathrm{TN}$ in the range of $20.7 \%-66,9 \%$ and $38.1 \%-51.6 \%$, respectively, and $\mathrm{Wu}$ et al. (2015b) reported values of 32\%-61\% for $\mathrm{NH}_{4}{ }^{+}$removal and $13 \%-44 \%$ for $\mathrm{TN}$ removal (Wu et al., 2015b). On the other hand, CW2 presented satisfactory efficiencies in the removal of $\mathrm{NH}_{4}^{+}(98.6 \%)$ and TN (81.2\%). Fig. 4 presents the dynamics of transformation of nitrogen in the two HFCWs.

Note that the concentrations of $\mathrm{NH}_{4}^{+}$declined rapidly in CW2, reaching average values of 7.1, 1.2, and $0.5 \mathrm{mg} \mathrm{L}^{-1}$ with 1,2 , and 3 days of HRT, respectively. In contrast, $\mathrm{CW} 1$ had a lower efficiency in the removal of $\mathrm{NH}_{4}^{+}$, with a final average concentration of $16.5 \mathrm{mg}$ $\mathrm{L}^{-1}$. These results were anticipated, as this system presented anaerobic conditions $\left(\mathrm{DO}=0.3-0.8 \mathrm{mg} \mathrm{L}^{-1}\right)$ that consequently limited nitrification. The removal of $\mathrm{NH}_{4}^{+}$in CW2 exceeded $98.6 \%$, corroborating the findings of Li et al. (2014), who also reported a near total removal of $\mathrm{NH}_{4}^{+}$. Moreover, the removal of $\mathrm{NH}_{4}^{+}$ in CW2 was $40.9 \%$ higher than that observed in CW1 $(57.7 \%$ vs $98.6 \%)$. Likewise, increases in the $\mathrm{NH}_{4}^{+}$ removal efficiency between intermittently aerated systems and non-aerated systems of $46 \%, 65 \%$ and $45 \%-88 \%$ have been reported by Uggetti et al. (2016), Fan et al. (2016), and Liu et al. (2019), respectively. Finally, these results show that artificial aeration creates adequate conditions for the effective occurrence of nitrification in HFCWs.

The CW2 wetland presented lower final concentrations of TN $\left(7.6 \mathrm{mg} \mathrm{L}^{-1}\right)$ than the non-aerated system $\left(20.8 \mathrm{mg} \mathrm{L}^{-1}\right)$, and the average removal efficiencies of $\mathrm{TN}$ were equal to $48.8 \%$ in $\mathrm{CW} 1$ and $81.2 \%$ in CW2. Therefore, these data show that the CW2 was $32.4 \%$ more efficient in the removal of $\mathrm{TN}$ than CW1. These results are higher than those obtained

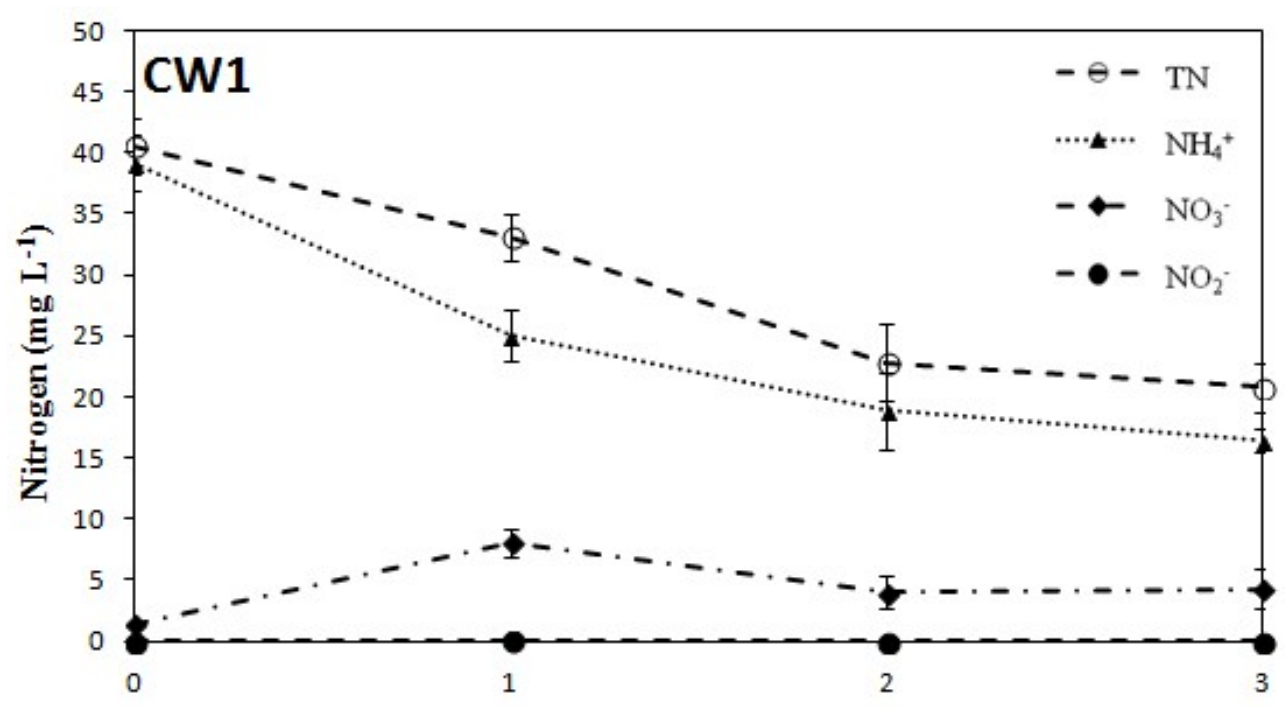

Hydraulic retention time (days)

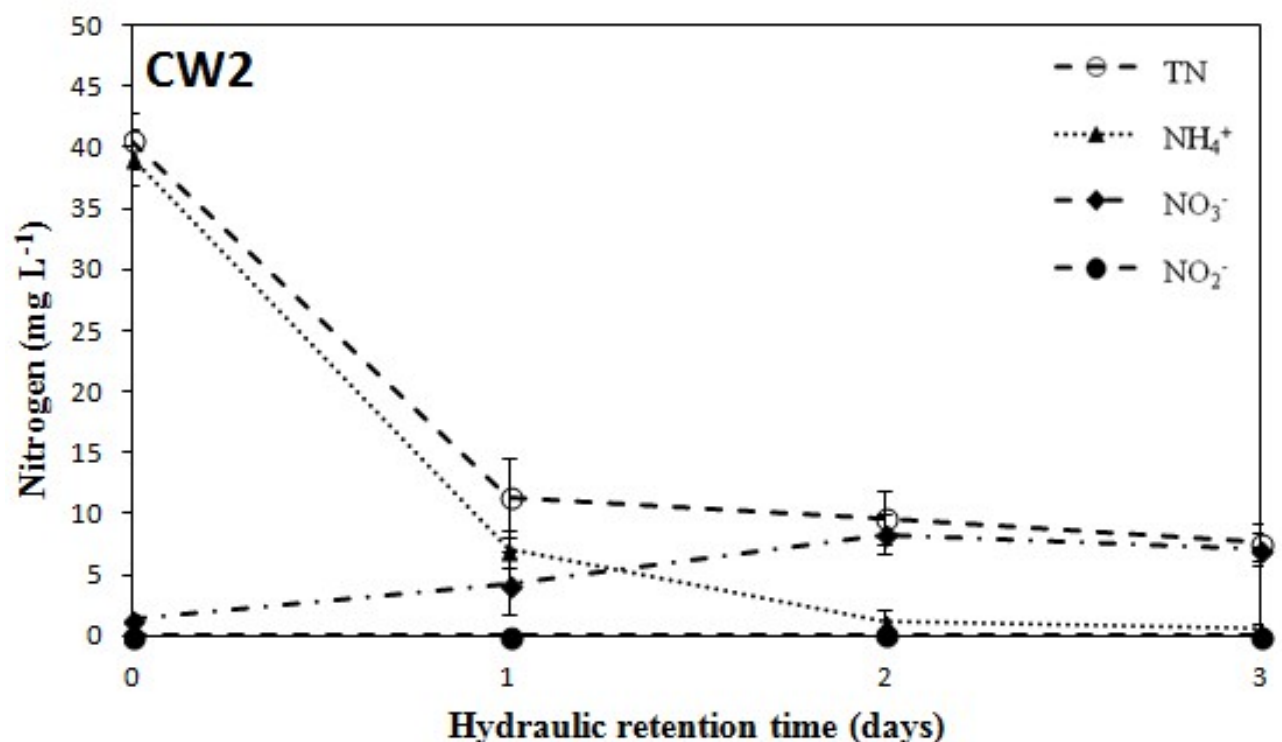

Fig. 4 Nitrogen transformation dynamics in the two HFCWs. 
by Uggetti et al. (2016) (improvement of 23\%) and lower than those reported by Liu et al. (2019) (improvements of $37 \%$ to $81 \%$ ). These findings suggest that intermittent aeration permitted the occurrence of nitrification and denitrification simultaneously in HFCWs, thus increasing the efficiency of TN removal.

The average concentrations of $\mathrm{NO}_{2}^{-}$registered during the experiment were very low $\left(<0.3 \mathrm{mg} \mathrm{L}^{-1}\right)$, indicating that the conversion of $\mathrm{NO}_{2}^{-}$to $\mathrm{NO}_{3}^{-}$occurs rapidly. The CW1 effluent was composed mainly of $\mathrm{NH}_{4}^{+}$owing to limited nitrification. The effluent from $\mathrm{CW} 2$ in turn was composed almost exclusively of $\mathrm{NO}_{3}^{-}$, indicating that nitrification was effective. However, although the data indicate that nitrification and denitrification occur simultaneously, the accumulation of $\mathrm{NO}_{3}^{-}$in these effluents indicates that complete denitrification did not occur, probably owing to the lack of organic carbon. $\mathrm{Wu}$ et al. (2016a) also reported that the lack of carbon prevented the complete denitrification of effluent in an intermittently aerated VFCW.

\section{Data statistical analysis}

The ANOVA performed on COD, $\mathrm{NH}_{4}^{+}$, and TN data indicated a statistically significant difference $(\mathrm{p}<0.05)$ between the CW1 and CW2 $(\mathrm{P}<0.0000)$, i.e., the use of intermittent aeration changed the removal efficiency of $\mathrm{COD}, \mathrm{NH}_{4}{ }^{+}$, and $\mathrm{TN}$ in the HFCW.

\section{CONCLUSIONS}

Intermittent aeration allows the simultaneous occurrence of nitrification and denitrification, thus improving the performance of HFCWs in the removal of $\mathrm{TN}$ and $\mathrm{NH}_{4}^{+}$. Additionally, intermittently aerated HFCWs also display a higher rate of removal of COD compared to non-aerated systems. However, the lack of organic carbon may limit the denitrification in systems with intermittent aeration. Finally, our results show that intermittently aerated HFCWs show high efficiency in the removal of COD $(97.6 \%)$, TN $(81.2 \%)$, and $\mathrm{NH}_{4}{ }^{+}$ $(>97 \%)$ and, therefore, are a viable option for the effective treatment of wastewater in isolated communities.

However, some limitations of the present study should be highlighted: 1) Synthetic effluent: although allowing the evaluation of nitrogen removal dynamics in HFCWs, the synthetic effluent is composed of simple substances that can be easily biodegraded and, therefore, do not adequately represent the complexity of a real effluent; 2) DO concentrations: the values obtained were determined on the center of the HFCWs at $10 \mathrm{~cm}$ deep, that is, in a single location above the air diffuser and thus, the concentrations obtained may not represent adequately the general distribution of DO in the systems under study. Thus, to consolidate the understanding of the effects of intermittent aeration in HFCW, it is necessary to conduct studies with nonsynthetic effluents and that also evaluate more consistently the spatial and temporal distributions of dissolved oxygen.

Acknowledgment The authors thank the São Paulo Research Foundation (FAPESP) for the grant of a scholarship (FAPESP Process 2017/18075-8).

\section{REFERENCES}

Abou-Elela, S.I., Golinielli, G., Abou-Taleb, E.M. \& Hellal, M. S. (2013) Municipal wastewater treatment in horizontal and vertical flows constructed wetlands. Ecological Engineering, 61, 460468, doi:10.1016/i.ecoleng.2013.10.010.

APHA, (2012). Standard Methods for the Examination of Water and Wastewater (22nd ed.). Washington, APHA.

Butterworth, E., Dotro, G., Jones, M., Richards, A., Onunkwo, P., Narroway, Y. \& Jefferson, B. (2013) Effect of artificial aeration on tertiary nitrification in a full-scale subsurface horizontal flow constructed wetland. Ecological Engineering, 54, 236-244, doi:10.1016/j.ecoleng.2013.01.034.

Caselles-Osorio, A., Vega, H., Lancheros, J.C., Casierra-Martínez, H.A. \& Mosqueraa, J.E. (2017) Horizontal subsurface-flow constructed wetland removal efficiency using Cyperus articulatus. L. Ecological Engineering, 99, 479-485, doi:10.1016/j.ecoleng.2016.11.062.

Chen, Y., Wen, Y., Zhou, Q. \& Vymazal, J. (2014) Effects of plant biomass on nitrogen transformation in subsurface-batch constructed wetlands: a stable isotope and mass balance assessment. Water Research, 63, 158-167, doi:10.1016/j.watres.2014.06.015.

Fan, J.L., Zhang, B., Zhang, J., Ngo, H.H., Guo, W.S., Liu, F.F., Guo, Y.Y. \& Wu, H.M. (2013) Intermittent aeration strategy to enhance organics and nitrogen removal in subsurface flow constructed wetlands. Bioresource Technology, 141, 117-122, doi:10.1016/i.biortech.2013.03.077.

Fan, J., Zhang, J., Guo, W., Liang, S. \& Wu, H. (2016) Enhanced long-term organics and nitrogen removal and associated microbial community in intermittently aerated subsurface flow constructed wetlands. Bioresource Technology, 214, 871-875, doi:10.1016/j.biortech.2016.05.083.

Hou, J., Xia, L., Ma, T., Zhang, Y., Zhou, Y. \& He, X. (2017) Achieving short-cut nitrification and denitrification in modified intermittently aerated constructed wetland. Bioresource Technology, 210, 101-107, doi:10.1016/j.biortech.2017.02.027.

Hua, Y., Peng, L., Zhang, S., Heal, K.V., Zhao, J. \& Zhu, D. (2017) Effects of plants and temperature on nitrogen removal and microbiology in pilot-scale horizontal subsurface flow constructed wetlands treating domestic wastewater. Ecological Engineering, 108, 70-77, doi:10.1016/j.ecoleng.2017.08.007.

Li, F., Lu, L., Zheng, X., Ngo, H.H., Liang, S., Guo, W. \& Zhang, X. (2014) Enhanced nitrogen removal in constructed wetlands: effects of dissolved oxygen and step feeding. Bioresource Technology, 169, 395-402, doi:10.1016/j.biortech.2014.07.004.

Lin, Y.F., Jing, S.R., Wang, T.W. \& Lee, D.Y. (2002) Effects of macrophytes and external carbon sources on nitrate removal from groundwater in constructed wetlands. Environmental Pollution, 119, 413-420, doi:10.1016/s0269-7491(01)00299-8.

Liu, F.F., Fan, J., Du, J., Shi, X., Zhang, J. \& Shen, Y. (2019) Intensified nitrogen transformation in intermittently aerated constructed wetlands: Removal pathways and microbial response 
mechanism. Science of the Total Environment, 650, 2880-2887, doi:10.1016/j.scitotenv.2018.10.037.

Liu, X., Zhang, Y., Li, X., Fu, C., Shi, T. \& Yan, P. (2018) Effects of influent nitrogen loads on nitrogen and COD removal in horizontal subsurface flow constructed wetlands during different growth periods of Phragmites australis. Science of the Total Environment, 635, 1360-1366, doi:10.1016/j.scitotenv.2018.03.260.

Maltais-Landry, G., Maranger, R., Brisson, J. \& Chazarenc, F. (2009). Nitrogen transformation and retention in planted and artificially aerated constructed wetlands. Water Research, 43, 535-545, doi:10.1016/j.watres.2008.10.040.

Saeed, T. \& Sun, G. (2012) A review on nitrogen and organics removal mechanisms in subsurface flow constructed wetlands: dependency on environmental parameters, operating conditions and supporting media. Journal of Environmental Management, 112, 429-448, doi:10.1016/j.jenvman.2012.08.011.

Uggetti, E., Hughes-Riley, T., Morris, R.H., Newton, M.I., Trabi, C. L., Hawes, P., Puigagut, J. \& García, J. (2016) Intermittent aeration to improve wastewater treatment efficiency in pilot-scale constructed wetland. Science of the Total Environment, 559, 212 217, doi:10.1016/j.scitotenv.2016.03.195.

Weerakoon, G.M.P.R., Jinadasaa, K.B.S.N., Heratha, G.B.B., Mowjoodb, M.I.M. \& Vanbruggen, J.J.A. (2013) Impact of the hydraulic loading rate on pollutants removal in tropical horizontal subsurface flow constructed wetlands. Ecological Engineering, 61, 154-160, doi:10.1016/j.ecoleng.2013.09.016.

Wu, H., Fan, J., Zhang, J., Ngo, H.H., Guo, W., Hu, Z. \& Liang, S. (2015a) Decentralized domestic wastewater treatment using intermittently aerated vertical flow constructed wetlands: impact of influent strengths. Bioresource Technology, 176, 163-168, doi:10.1016/j.biortech.2014.11.041.

Wu, H., Fan, J., Zhang, J., Ngo, H.H. Guo, W., Liang, S., Lv, J., Lu, S., Wu, W. \& Wu, S. (2016a) Intensified organics and nitrogen removal in the intermittent-aerated constructed wetland using a novel sludge-ceramsite as substrate. Bioresource Technology, 210, 101-107, doi:10.1016/j.biortech.2016.01.051.

Wu, H., Fan, J., Zhang, J., Ngo, H.H., Guo, W., Hu, Z. \& Lv, J. (2016b) Optimization of organics and nitrogen removal in intermittently aerated vertical flow constructed wetlands: Effects of aeration time and aeration rate. International Biodeterioration \& Biodegradation, 113, 139-145, doi:10.1016/j.ibiod.2016.04.031.

Wu, S., Kuschk, P., Brix, H., Vymazal, J. \& Dong, R. (2014) Development of constructed wetlands in performance intensifications for wastewater treatment: a nitrogen and organic matter targeted review. Water Research, 57, 40-55, doi:10.1016/j.watres.2014.03.020.

Wu, S., Lei, M., Lu, Q., Guo, L. \& Dong, R. (2015b) Treatment of pig manure liquid digestate in horizontal flow constructed wetlands: Effect of aeration. Engineering in Life Sciences, 16, 263-271, doi:10.1002/elsc.201500030.

Wu, H., Zhang, J., Wei, R., Liang, S., Li, C. \& Xie, H. (2013). Nitrogen transformations and balance in constructed wetlands for slightly polluted river water treatment using different macrophytes. Environmental Science and Pollution Research, 20, 443-451, doi:10.1007/s11356-012-0996-8. 